\title{
STEROID METABOLISM BY THE SEMINIFEROUS TUBULES IN VITRO AND SPERMATOGENESIS IN THE DEVELOPING RAT
}

\author{
W. N. TSANG, P. M. COLLINS AND D. LAGY \\ Department of Zoology, St Bartholomew's Medical College, \\ Charterhouse Square, London, E.C.1
}

(Received 1st Fanuary 1973)

Androgens are capable of maintaining the progressive development of the germ cells in immature male rats which have either been hypophysectomized (Leathem, 1944; Ludwig, 1950; Lostroh, 1969) or treated with compounds which interfere with the release and/or secretion of gonadotrophins (Ludwig, 1950; Kalra \& Prasad, 1967; Steinberger \& Steinberger, 1969). Similar results have also been obtained in adult male rats (Boccabella, 1963; Clermont \& Harvey, 1967; Lacy \& his co-authors, 1969). Studies on steroid metabolism in vitro by isolated seminiferous tubules of rats denuded of their germ cells by heattreatment has led to the view that not only Leydig cells but also Sertoli cells may be a major source of androgens (Collins, Bell \& Vinson, 1968; Lacy et al., 1969). Similar conclusions have also been reached by Ellis \& van Kampen (1971) from studies on tubules in which the ratio of Sertoli cells to germ cells was altered artificially by irradiation. Since there appear to be two main sources of androgens in the testis, spermatogenesis may be dependent upon testosterone produced by the Leydig cells, by the Sertoli cells or by both. Changes in testosterone production in vitro by the interstitium of developing rats have been reported previously (Tsang, Lacy \& Collins, 1973). In the present work, the relationship between spermatogenesis and steroid metabolism in vitro by isolated tubules has been studied in the rat from pre-puberty to maturity. This approach has also provided an opportunity to examine steroid metabolism by the tubules under conditions in which there was a naturally occurring change in the ratio of Sertoli cells to germ cells. Since changes in testosterone production during development may be regulated by $5 \alpha$-reductase activity (Nayfeh, Barefoot \& Baggett, 1966), a comparison was also made between this activity in the tubules and in the interstitium.

Tubules were obtained by dissection from the same testes as those which provided the tissue for previous studies on the interstitium (Tsang et al., 1973). One series of incubations was carried out for $2 \mathrm{hr}$ using $200 \mathrm{mg}$ wet weight of tissue obtained from four animals of five age-groups (30,35, 45, 56 and 73 days), giving a total of twenty 'fixed time' incubations. A second series of incubations, using $400 \mathrm{mg}$ wet weight of tissue obtained from three additional animals in each age-group, was carried out for $6 \mathrm{hr}$ and samples of the medium were withdrawn at successive intervals of time (kinetic incubations). The tubules 
were incubated with either $0.1 \mu \mathrm{Ci}$ ('fixed time' incubations) or $0.2 \mu \mathrm{Ci}$ (kinetic studies) of $\left[4-{ }^{14} \mathrm{C}\right]$ progesterone in Krebs-Ringer bicarbonate at $32.7^{\circ} \mathrm{C}$. Steroids were extracted, characterized and identified using procedures similar to those reported in related work from this laboratory (Bell, Vinson \& Lacy, 1971). The total weight of the tubules per testis was determined by weighing the tubules obtained from a standard amount of whole tissue and relating this to the weight of the entire organ from which the tunica albuginea had been

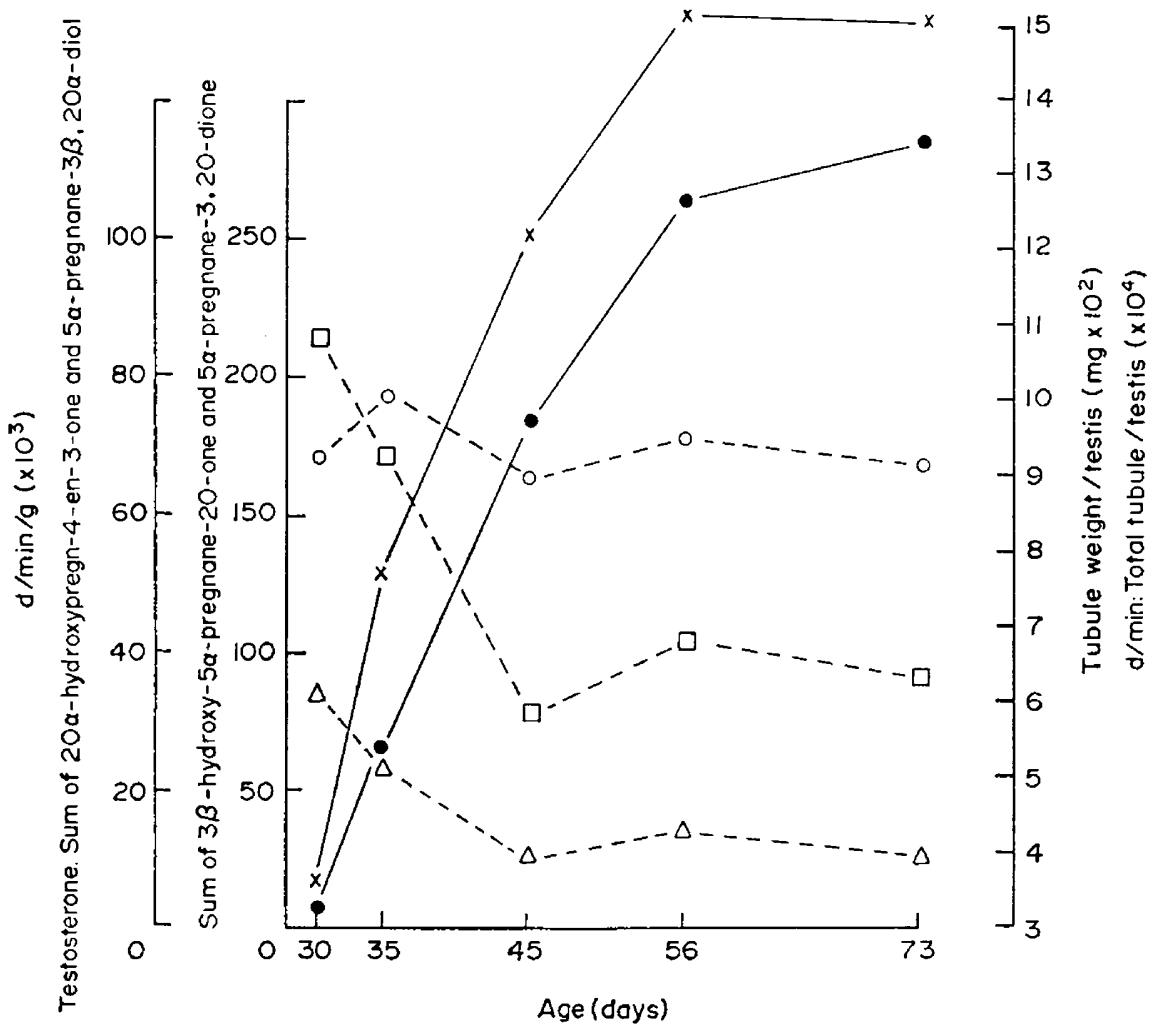

TExt-Fic. 1. Relationship between the weight of the seminiferous tubules and the yields of products from $\left[4-{ }^{14} \mathrm{C}\right]$ progesterone in the rat during development. $\times$, Sum of the yields of $3 \beta$-hydroxy-5 $\alpha$-pregnane-20-one and $5 \alpha$-pregnane-3,20-dione (total tubule weight/ testis); $\bullet$, total tubule weight/testis; $\square$, testosterone $(\mathrm{d} / \mathrm{min} / \mathrm{g}) ; \Delta$, sum of the yields of

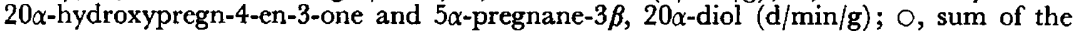
yields of $3 \beta$-hydroxy-5 $\alpha$-pregnane-20-one and $5 \alpha$-pregnane-3,20-dione $(\mathrm{d} / \mathrm{min} / \mathrm{g})$.

first removed. Samples of whole tissue obtained from five rats aged 22 days, together with those referred to above, were fixed in Bouin's fluid and stained with iron haematoxylin and orange $G$ to demonstrate various stages of spermatogenesis.

By 22 days, the development of the germ cells had progressed as far as early pachytene. By Day 30, the cells had completed their reduction divisions so that some tubules contained spermatogonia and two generations of spermatocytes while in others, the oldest generation of spermatocytes had given rise to some young (Golgi phase) spermatids. By Day 45 , some tubules contained spermatids 
in the late acrosome to maturation phase while at Day 56 , spermatids together with conspicuous residual bodies were observed in the lumina of the tubules. In these animals, therefore, the period from Day 22 to Day 30 was one in which the germ cells completed their reduction divisions and thus passed through a stage of development known to be responsive to androgens. The period from Day 30 to Day 56 was essentially one of spermiogenesis during which the tubules acquired their full complement of germ cells and the weight of the tubules rose to the adult range (Text-fig. 1).

Both in the 'fixed time' and kinetic incubations, the principal metabolites obtained were $17 \alpha$-hydroxyprogesterone, androstenedione, testosterone, $20 \alpha$ hydroxypregn-4-en-3-one, $5 \alpha$-pregnane- $3 \beta, 20 \alpha$-diol, $3 \beta$-hydroxy- $5 \alpha$-pregnane-

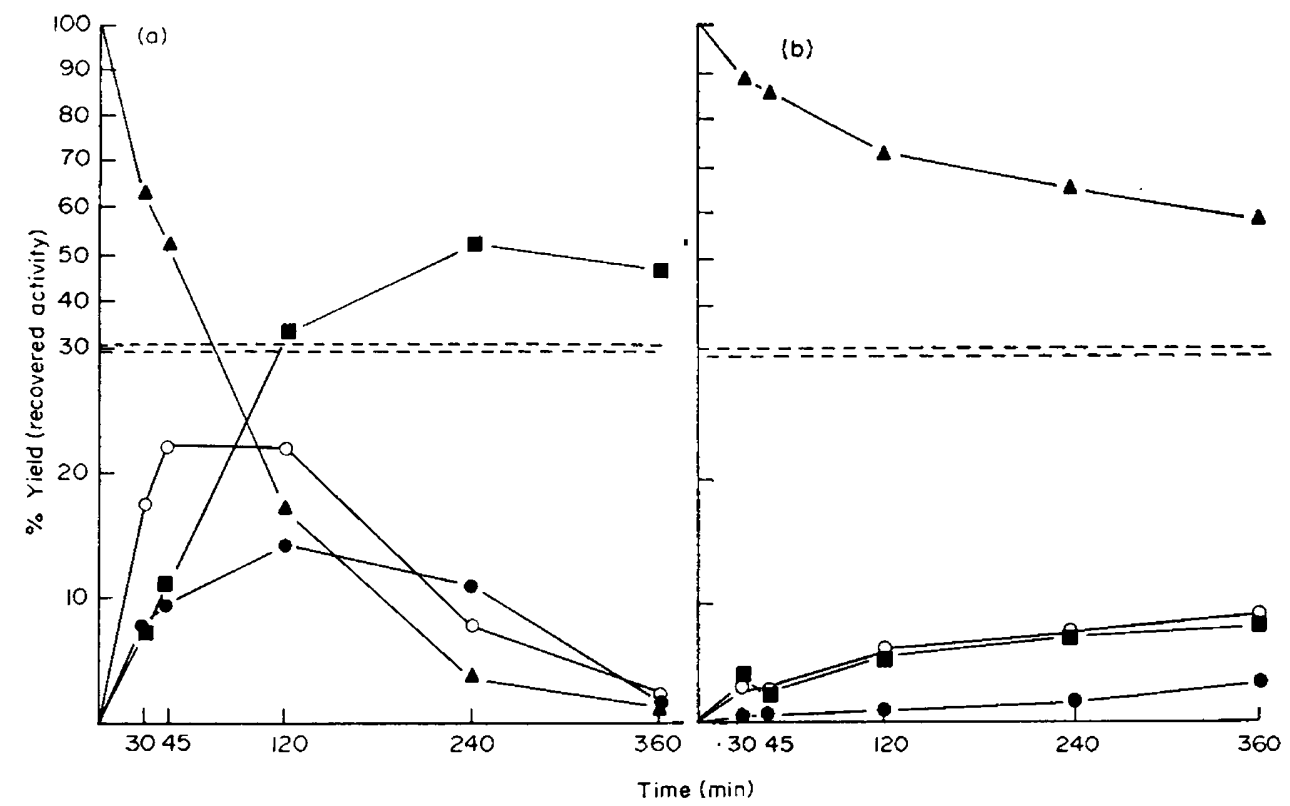

Text-Fig. 2. Typical yield-time curves for products from $\left[4-{ }^{14} \mathrm{C}\right]$ progesterone during incubation with isolated seminiferous tubules from rats aged 30 days (a) and 73 days (b). $\Lambda$, Progesterone; $0,17 \alpha$-hydroxyprogesterone; $O$, androstenedione; $\mathbf{m}$, testosterone.

20 -one and $5 \alpha$-pregnane-3,20-dione. The formation of large amounts of $5 \alpha$ pregnane compounds is evidence for the presence of high levels of $5 \alpha$-reductase in the seminiferous tubules acting primarily on progesterone. This contrasts with the situation previously described for the interstitium where androsterone was the principal product of ring A reduction (Tsang et al., 1973). This suggests a high measure of substrate specificity for $5 \alpha$-reductase in the two tissues and accounts for the formation of relatively large amounts of both $5 \alpha$-androstane and $5 \alpha$-pregnane compounds in incubations with cell fractions obtained from entire testes (see Inano, Hori \& Tamaoki, 1967).

In the 'fixed time' incubations, maximum yields of testosterone per unit wet weight of tissue were obtained at 30 days. The yields then rapidly declined, significantly lower values being obtained from Day 45 to Day $73(P<0.01$, Text-fig. 1). In the kinetic incubations, the rate of metabolism of progesterone 
and the formation of testosterone was much greater at 30 days than at any of the later periods, with the various metabolites forming well-defined sequential maxima in the former case but not in the latter (cf. Text-fig. 2a and b). It is apparent that maximal production of testosterone occurred at a time when the ratio of Sertoli cells to germ cells was relatively high and fell sharply as the number of germ cells and weight of the tubules increased. It is also apparent that the high production of testosterone at Day 30 coincided with the end of the first successful meiotic divisions. The production of testosterone per unit wet weight then decreased as development proceeded, reaching a comparatively low level at a time when spermiogenesis was well advanced. This period (from Day 30 onwards) corresponded with a marked increase in testosterone production by the interstitium (Tsang et al., 1973). This suggests that androgens produced by the interstitium may play some rôle in spermiogenesis and the subsequent maintenance of spermatogenesis in adult animals. The reduced production of testosterone by the tubules, however, may simply indicate that whereas relatively large amounts of androgens were needed to initiate spermatogenesis, much less is needed to complete the process and maintain it. This is in accord with several studies on the effect of administering androgens to hypophysectomized or oestrogen-treated animals where it has been consistently found more difficult to initiate spermatogenesis with androgens once the testis has been allowed to atrophy (Boccabella, 1963; Clermont \& Harvey, 1967; Lacy et al., 1969).

There was a direct correlation between the yields of testosterone per unit wet weight of tissue and the yields of the products of $20 \alpha$-hydroxysteroid dehydrogenase activity (20 $\alpha$-hydroxypregn-4-en-3-one and $5 \alpha$-pregnane, $3 \beta, 20 \alpha$-diol, Text-fig. 1). As in the case of testosterone, significantly lower values were obtained from Day 45 onwards than those at Day $30(P<0 \cdot 01)$. This suggests that whatever influences the production of testosterone in vitro also influences the yields of the other two metabolites. The most obvious interpretation is that all are dependent upon a common substrate and probably have the same cellular origin. In all cases, the evidence points to the Sertoli cells as the most likely source, a view which is in accord with observations on heat-treated tissue where

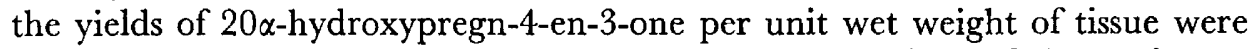
more than eight times the control values while the weight of the testis was reduced by half (Collins et al., 1968; Lacy et al., 1969).

Unlike all other metabolites, the yields of $3 \beta$-hydroxy-5 $\alpha$-pregnane-20-one and $5 \alpha$-pregnane-3,20-dione per unit wet weight of tissue remained constant during the period under examination and no significant differences were observed among any of the age groups studied (Text-fig. 1). Hence, there was a marked increase in both when the yields were expressed in terms of the progressive gain in weight of the tubules (Text-fig. 1). Since the increase in weight of the tubules was due mainly to an increase in the number of germ cells and primarily to the formation of two generations of spermatids, it seems likely that the latter types of cells were mainly responsible for the increase in total production of the two $5 \alpha$-pregnane compounds. This does not exclude the possibility of some contribution by germ cells in earlier stages of development or by the Sertoli cells or cells of the boundary tissue, all of which were present before spermiogenesis became well established, i.e. by Day 30 . 
It is a pleasure to acknowledge the financial support of the Wellcome Trust, Schering Chemicals and the Joint Research Board of St Bartholomew's Hospital and Medical College.

\section{REFERENCES}

BeLL, J. B. G., Vinson, G. P. \& LACY, D. (1971) Studies on the structure and function of the mammalian testis. III. In vitro steroidogenesis by the seminiferous tubules of the rat testis. Proc. $R$. Soc. B, 176, 433.

BocGABelLA, A. V. (1963) Reinitiation and restoration of spermatogenesis with testosterone propionate and other hormones after a long-term post-hypophysectomy regression period. Endocrinology, 72, 787.

Clermont, Y. \& Harvey, S. G. (1967) Effects of hormones on spermatogenesis in the rat. Ciba Fdn Colloq. Endocr. 16, 105.

Collins, P. M., Bell, J. B. G. \& Vinson, G. P. (1968) The effects of elevated temperature on testis function. In: 6th Congrès de Reproduction et Insemination Artificielle, Paris, 1968, p. 261. Ed. C. Thibault. Institut National de la Recherche Agronomique, Jouy-en-Josas, France.

Ellis, L. G. \& van KAMPEN, K. R. (1971) Androgen synthesis and metabolism by rat testicular minced and teased-tubular preparations after $450 \mathrm{R}$ of whole-body X-irradiation. Radiat. Res. 48, 146.

InANO, H., Hori, Y. \& TAMAOKI, B. (1967) Effect of age on testicular enzymes related to steroid bioconversion. Ciba Fdn Colloq. Endocr. 16, 105.

KALRA, S. P. \& PRASAD, M.R. N. (1967) Effect of FSH and testosterone propionate on spermatogenesis in immature rats treated with clomiphene. Endocrinology, 81, 965.

Lacy, D., Vinson, G. P., Collins, P., Bel., J. B. G., Fyson, P., Pudney, J. \& Pettrtt, A. J. (1969) The Sertoli cell and spermatogenesis in mammals. In: Progress in Endocrinology, Proc. 3rd Int. Congr. Endocr., Mexico, 1968, p. 1019. Ed. G. Gual. Excerpta Medica Foundation, Amsterdam.

LEATHEM, J. H. (1944) Influence of testosterone propionate on the adrenals and testes of hypophysectomized rats. Anat. Rec. 89, 155.

LOSTROH, A. J. (1969) Regulation by FSH and ICSH (LH) of reproductive function in the immature male rat. Endocrinology, 85, 438.

LuDwig, D. J. (1950) The effect of androgens on spermatogenesis. Endocrinology, 46, 453.

NAYFeH, S. N., BAREFoot, S. W. \& BAgGeTt, B. (1966) Metabolism of progesterone by rat testicular homogenates. II. Changes with age. Endocrinology, 78, 1041.

Steinberger, E. \& Steinberger, A. (1969) The spermatogenic function of the testes. In: The Gonads, p. 715. Ed. K. W. McKerns. North Holland Publishing Co., Amsterdam.

Tsang, W. N., LAcY, D. \& Collins, P. M. (1973) Leydig cell differentiation, steroid metabolism by the interstitium in vitro and the growth of the accessory sex organs in the rat. F. Reprod. Fert. 34, 353. 